\title{
1 Influence of the quality of recycled aggregates on the 2 mechanical and durability properties of High 3 Performance Concrete
}

Andreu GONZALEZ-COROMINAS ${ }^{1}$, Miren ETXEBERRIA ${ }^{1 *}$, Chi-sun POON²

1. Department of Construction Engineering, Polytechnic University of Catalonia, Jordi Girona, 1-3 B1 building, Barcelona 08034, Spain.

I* Dr. Eng. Associate professor, Department of Construction Engineering, Polytechnic University of Catalonia, Jordi Girona, 1-3 B1 building, Barcelona 08034, Spain, telephone: +34934011788, Fax: +34934017262, E-mail: miren.etxeberria@upc.edu.

${ }^{2}$ Department of Civil and Environmental Engineering, the Hong Kong Polytechnic University, Hung Hom, Kowloon, Hong Kong.

Abstract

The main objective of this experimental work is to analyse the effect of recycled aggregates (RA), on the basis of the study of the various qualities, of the physical, mechanical and durability properties of High Performance Concrete (HPC). Five types of recycled aggregates: three coarse RA sourced from parent ceramic waste aggregates; mixed recycled aggregates.

\section{INTRODUCTION}


1 High performance concrete (HPC) is designed to have better mechanical properties and higher workability and resistance to aggressive chemicals than traditional concrete [1]. Certain demolition waste materials have been successfully used in the manufacture of conventional concrete, and even in HPC.

The suitability of recycled concrete aggregate (RCA) for use in different applications with a low or moderate degree of requirement has been extensively tested and proved by many authors [2-13]. Taking into consideration the properties of RCA in concrete production, both the dosage method and substitution rates of the natural aggregate were established in order to achieve adequate fresh and hardened properties, comparable to those of natural aggregate concrete (NAC).

Ceramic waste also represents an important amount of the construction and demolition waste that reaches recycling and treatment plants [14]. Unfortunately this waste is usually combined with waste from other inorganic materials. These materials have a negative effect on the properties' results of mixed recycled aggregates (MRA), which show lower technical properties. It is evident that selective demolition will represent a more appropriate recycling method of achieving a more efficient and sustainable reuse of ceramic materials [15].

The suitability of ceramic material as recycled aggregates or cementitious material for use in different applications with a low or moderate degree of requirement (lower compressive strength than that defining HPC, 62MPa according to ACI [16]), has been extensively tested and proved by many authors [17-26].

De Brito et al. [14] stated that the disparity in water absorption between secondary (or ceramic waste) and natural aggregates will be the main difficulty in the employment of ceramic aggregates in particular, in the production of concrete that does not lose in strength, workability or durability. However, according to certain research works recycled concrete could achieve the properties of conventional concrete when the natural aggregates are replaced by ceramic aggregates. Torkittikul and Chaipanich [23] and Khatib [26] studied the mechanical properties of concrete produced with fine ceramic waste aggregates (CWA). Torkittikul [23] established 50\% of CWA, produced by crushing earthenware ceramic waste, as the optimum replacement ratio in order to maintain similar workability and compressive strength to that of conventional concrete. Khatib [26] extended the statement to long-term compressive strength, recommending the use of $50 \%$ of CWA, produced from crushed bricks, in the substitution of natural sand 
1 for concrete production. However, Khatib [26] affirmed that even at 100\% of fine aggregate replacement the reduction in strength was only $10 \%$ and indicated that this could be due to the cementing action in the presence of that type of CWA. Pacheco-Torgal and Jalali [20] found that concrete mixtures employing ceramic sand achieved durable concrete.

However, the use of these recycled materials is important in HPC since the growth of the extensive worldwide use of HPC. Certain authors [4,5,27-29] have suggested that the use of coarse RCA could be extended to high performance concrete (HPC), thus offering additional value to RAC.

Limbachiya [27] examined the influence of coarse RCA in high-strength concrete, $50 \mathrm{MPa}$ or more. The concrete performance was assessed, and the practical issues and durability properties were dealt with. The results obtained showed that concrete containing up to $30 \%$ of coarse RCA could be used in a wide range of high performance engineering applications and the durability properties were similar to those of NAC concrete.

Moreover, Ajdukiewicz and Kliszczewicz [28] and Gonzalez and Etxeberria [29] studied high performance concrete using RCA obtained from medium and high strength demolition concrete and analysed their influence on concrete properties. The properties of the original concrete had a significant influence on the mechanical properties of the recycled aggregate concrete (RAC); the RAC obtained higher compressive strength than conventional concrete when the RCA was produced with HPC aggregates.

Relatively speaking, it must be noted that few studies have examined the use of recycled ceramic aggregates in High Performance Concrete [30-32] or suggested that the use of recycled ceramic materials could enhance HPC, offering an additional value to the ceramic waste. Suzuki et al. [31] used porous coarse ceramic waste aggregates for the internal curing of high performance concrete. Their research exposed that there was a high effectiveness of the ceramic aggregates in reduction of, and even complete elimination of autogenous shrinkage. The incorporation of $40 \%$ of coarse mixed aggregate led to a nonshrinking HPC which was accompanied by a significant increase of compressive strength. The use of ceramic waste material as fine admixtures has proved to have positive values as an additional binder which could prove to be very useful in HPC. If ceramic minerals are mixed with calcium hydroxide and 
1 water, pozzolanic reactions can form new compounds, thus increasing the strength and durability

2 properties of the concrete [32].

3 In this paper the influence of the quality of recycled aggregates and their replacement ratio on the 4 properties of HPC was evaluated. The natural aggregate concrete (NAC) was designed to achieve 100 $5 \quad \mathrm{MPa}$ compressive strength in order to comply with the regulations governing Spanish railway sleeper

6 specification [33], as well as meeting all the technical requirements for its application in precast-concrete

7 factories. Four different coarse recycled aggregates, three types of coarse RCA and one coarse MRA, and one fine ceramic waste aggregates (CWA) were used in order to analyse their influence on the physical, mechanical and durability properties of HPC. The results obtained by recycled aggregate concretes were compared to those of NAC mixtures.

\section{EXPERIMENTAL DETAILS}

\subsection{Materials}

\subsubsection{Cement and admixture}

ASTM Type I Portland cement (CEM I 52.5R) was used in all concrete mixtures. The cement had a characteristic rapid hardened strength of $52.5 \mathrm{MPa}$, low alkali content and specific surface of 4947.8 $\mathrm{cm}^{2} / \mathrm{g}$. Rapid hardened cement was used in order to achieve concretes with 1-day compressive strength higher than $46 \mathrm{MPa}$ in compliance with the requirements defined for concretes in railway sleeper production [33]. The chemical properties of the cement are given in Table 1.

A high performance admixture, superplasticizer based on polycarboxilate-ether, was used for all concrete production to a ratio of $1.5 \%$ of cement weight, as required for the manufacturing of railway sleepers.

\subsubsection{Aggregates}

Two types of coarse natural aggregates (NA) and two types of river sands were used for the production of the conventional concrete. The mixture proportioning followed that used in HPC for sleeper manufacture. The two types of coarse natural aggregates (NA) were: crushed dolomite and river gravel. Two different types of natural river sand (River Sand 1 and 2) were used as fine natural aggregate in all the concrete 
mixtures. Both river sands showed essentially siliceous particles (quartz and feldspars). The use of river sand improved the workability and toughness of the concrete.

Four types of coarse recycled aggregates were assessed, three Recycled Concrete Aggregates (RCA) and one Mixed Recycled Aggregate (MRA). The RCAs which were found to contain different characteristic strengths $(100,60$ and $40 \mathrm{MPa})$ were sourced from precast concrete wastes, the crushing of which took place in the laboratory (they were nominated as RCA100, RCA60 and RCA40). The MRA containing $67 \%$ ceramic waste was sourced from a treatment plant located in Catalonia (Spain). The compositions of the MRA and CWA are given in Table 2, and follow the specifications of EN-933-11. The MRA composition did not fulfil the ceramic aggregate classification requirements of the RILEM [34] and DIN standards [35] (>90\% or $>80 \%$ of ceramic content, respectively). The mixed aggregate category was adopted to define the MRA composition, in spite of showing a high proportion of ceramic components. The nominal sizes of the coarse natural aggregates, RCA100/60/40 and the MRA aggregates were $10 \mathrm{~mm}$ and $12.5 \mathrm{~mm}$, respectively and their particle size distributions are shown in Fig. 1. One can note that all the size grading of the natural and recycled coarse aggregate were similar. Therefore no grading adjustments were carried out before NA replacement.

Fine aggregates particle size distributions are shown in Fig. 2. River sand 1 had a higher amount of particles between $0.25-2 \mathrm{~mm}$ than River sand 2 in order to improve the compactness of the entire fine aggregates grading size distribution. Fine ceramic waste aggregates (CWA) were obtained by crushing rejected bricks from a local masonry company. The CWA was used as replacement for both of the natural fine aggregates mentioned. One can observe that the fine CWA showed higher ratios of filler and finer particles than the natural aggregates. However, the particle size distributions of the fine aggregates samples combined with $15 \%$ and $30 \%$ of CWA were adequate according to Spanish Structural concrete requirements [36].

Physical and mechanical properties of each type of aggregates were determined according to EN specifications. The results of the density and water absorption of the aggregates were determined according to the BS EN 1097-6:2001 regulation. The results of the flakiness, abrasion indexes and the crushing value were determined according to the BS EN 933-3:2012, BS EN 1097-2:2010 and BS 812110:1990 regulations, respectively. As Table 3 shows, the natural coarse aggregates had a higher density 
and lower absorption capacity than any other RCA and MRA. In contrast, when the original concrete had higher compressive strength, the RCA achieved better physical properties (RCA100 achieved a higher density and lower porosity than RAC60 and RAC40). However the three types of RCA had a lower absorption capacity than $7 \%$, which is the maximum absorption capacity required by the Spanish Structural concrete regulation [36]. MRA showed a water absorption capacity of $16.45 \%$, due to the high proportion of ceramic material (see Table 2). MRA had much lower percentages of natural and concrete aggregates with $9.8 \%$ and $22.2 \%$ respectively. The Los Angeles Index of all the aggregates were lower than $30 \%$, which indicates high strength to abrasion. Moreover the three types of RCA and MRA aggregates' index were similar, or even lower, to that from dolomitic coarse aggregate. Nevertheless, the aggregates crushing value revealed higher differences between recycled and natural aggregates. The MRA was much weaker $(34.62 \%)$ than the dolomitic aggregates $(20.15 \%)$. The fine CWA aggregates due to their high porosity not only obtained lower density $\left(2.0 \mathrm{~kg} / \mathrm{dm}^{3}\right)$ but also a much higher water absorption capacity ( $14.37 \%$ at 24 hours) than those of the river sands.

\subsection{Concrete mixtures}

All concrete mixtures were prepared and produced in the laboratory. The coarse recycled aggregates were used as $20 \%, 50 \%$ and $100 \%$ substitutions for coarse natural aggregates. The fine CWA was used as $15 \%$ and $30 \%$ substitutions for natural sands. Due to the low density of recycled aggregates, the replacement of natural aggregates (both fine and coarse aggregates) was carried out by volume. Following previous research [29] and other authors' procedure [2,31], the ratio between aggregates and concrete volumes was kept constant and no modifications on cement amount were conducted. The concrete mix proportions were defined according to the Fuller's method [38]. This was the method followed by the prestressed concrete railway sleeper manufacturer in the reference NAC mixture production. As shown in Table 4, $380 \mathrm{~kg}$ of cement and effective water -cement ratio of 0.285 were used in all concrete productions.

The effective water-cement ratio of the conventional concrete was determined (it is the ratio between the water weight, which would react with cement, and cement weight used for concrete production) and it was fixed as a constant value for all concretes. It was considered that the water which would react with the cement would be named effective water. In order to control the same effective water in all concretes, the moisture conditions of the aggregates were intensively controlled. The fine natural aggregates were 
used in oversaturation conditions with $3.5 \%-4 \%$ of humidity (the unabsorbed water was considered as part of the effective water). They were first moistened the day before use by means of a sprinkler system and then covered with a plastic sheet in order to maintain a high humidity level until their use in concrete production. The fine aggregates' moisture condition was essential in the controlling of the compressive strength of concretes at 1-day. The natural coarse aggregates were used in a dry condition and tests concluded that they absorbed $20 \%$ of their total water capacity at the concrete production stage (which was the water absorption capacity of aggregates submerged in water up to 30 minutes). The coarse recycled aggregates, RCA100, RCA60, RCA40 and MRA were also moistened the day before use in order to reduce their absorption capacity [2,7]. According to Poon et al. [37] and previous research [2,29], the RCA and MRA were not saturated as that would probably result in the failure of an effective interfacial transition zone (ITZ) between the saturated coarse mixed aggregates and the new cement paste. They were employed with approximately $80-90 \%$ of humidity of their absorption capacity and their effective absorption capacity was that of $70 \%$. Fine ceramic aggregate was used in dried conditions and its effective absorption capacity was that of $100 \%$. The total water amount of the concrete was considered as the amount of effective water weight plus the moisture (or absorbed water) of the aggregates (see Table 4).

Dry consistency was maintained in all concrete mixtures and the $1.5 \%$ respect to cement weight of superplasticizer was used in all mixtures, as required for the manufacturing of railway sleepers.

The recycled concrete mixtures were coded as $\mathrm{RAC}-\mathrm{x}(\mathrm{x}=$ type of recycled aggregate used).

\subsection{Specimens casting and curing}

For each concrete mixture, $100 \mathrm{~mm}$ cubes were used to test the hardened concrete density, absorption, the permeable pore voids, and capillary water absorption. The pore size distribution was determined for concretes produced with the three types of RCAs and natural aggregates. Compressive strength and flexural strength tests were conducted using $150 \mathrm{~mm}$ cubes and 100x100x400 prisms, respectively, in compliance with the requirements of the Spanish railway sleeper technical specification [33]. Moreover, $100 \varnothing / 200 \mathrm{~mm}$ cylinders were used to evaluate compressive strength (in order to establish correlation 
1 between different specimen dimensions), elastic modulus, splitting tensile strength and resistance to

2 chloride-ion penetration of the concrete.

3 All the specimens were-compacted using a vibrating table during two stages of 30 seconds duration. The concrete specimens were kept for a day in the moulds. The moulds were covered with a wet burlap and a plastic top to ensure that the temperature and wet conditions would remain stable between $18^{\circ} \mathrm{C}$ and $26^{\circ}$ $\mathrm{C}$ with a high moisture content. Specimens were demolded 24 hours after casting. Three cubes were immediately tested after demolding to measure 1-day compressive strength. The rest of the specimens were cured in a humidity room at $23^{\circ} \mathrm{C}$ and $95 \%$ humidity until the other testing ages were reached.

\subsection{Tests of hardened properties of concrete}

\subsubsection{Physical properties}

Density, absorption and volume of permeable pore space

The density, absorption and voids were measured following the ASTM C 642 - 97 "Standard Test Method for Density, Absorption, and Voids in Hardened Concrete" at 28 days. Three cube specimens were used in this test for each type of concrete produced.

\section{Pore structure}

The testing of porosity and pore structure was performed by Mercury Intrusion Porosimetry (MIP) with a 'Micromeritics Poresizer 9320’ mercury intrusion porosimeter according to BS7591 Part 1. This test was carried out on small concrete pieces, weighing approximately $5.5 \mathrm{~g}$, from concretes containing $100 \%$ of RCA (from parent concretes of 100, 60 and $40 \mathrm{MPa}$ ). The crushed samples were obtained from the $100 \mathrm{x}$ $100 \times 100 \mathrm{~mm}$ cubic specimens. The samples were first immersed in acetone for 4 days to stop the cement hydration and then introduced in a vacuum drier for 2 hours to extract the remaining acetone. Before testing, the samples were dried in an oven at $50^{\circ} \mathrm{C}$ for 4 days. Using the MIP technique, a measure of the total porosity of the sample as well as the surface area of the pore network was also obtained. The MIP test was conducted on the concrete samples cured at ages of 1 and 28 days and each result represents the average of three tested samples.

\subsubsection{Mechanical properties}


2 The compressive strength of concretes was determined using a compression machine with a loading capacity of $3000 \mathrm{kN}$. The compressive strength was measured at the ages of 1, 7 and 28 days for the cube specimens (in order to verify that they were in accordance with Spanish railway sleeper technical requirements [33]) and at the ages of 28 and 180 days for the cylinder specimens following BS-EN 12390-3 standards. Each presented value is the average of three measurements.

The flexural strength was measured following BS-EN 12390-5 at the age 7 days in accordance with the Spanish railway sleeper technical requirement [33]. The splitting tensile strength and elastic modulus were tested at 28 days also following BS-EN 12390-6 and UNE 83-316-96 BS-EN 12390-13 specifications, respectively. Three specimens were used for each type of concrete produced.

\subsubsection{Durability properties}

\section{Capillary water absorption}

The concrete's capillary water absorption was assessed using 100 x 100 x $100 \mathrm{~mm}$ cubic specimens at 28 days of curing and according to ISO 15148:2002(E). The specimens were previously oven-dried at $40^{\circ} \mathrm{C}$ until constant weight. Then the bottom face of the specimens was submerged in water to a depth of $5 \mathrm{~mm}$ (the lateral surfaces were impregnated with impermeable resin). The cumulative water absorbed was recorded at different time intervals up to 48 hours by weighing the specimen after removing the surface water using a dampened tissue for determination of capillary absorption capacity. Sorptivity is the slope of the regression curve of the amount of water absorbed by a unit surface area versus the square root of the elapsed time from initial instant to 120 minutes. The results of capillary water absorption as well as the results of sorptivity are the average of three measurements.

\section{Chloride ion penetrability}

The chloride penetrability of concrete was determined in accordance with ASTM C1202 (1997) using a $50 \mathrm{~mm}$ thick/100 $\varnothing \mathrm{mm}$ concrete sections cut from the middle of $100 \varnothing / 200 \mathrm{~mm}$ concrete cylinders. The two middle sections obtained from one cylinder were tested at different ages. The external $5 \mathrm{~mm}$ sections of the cylindrical were rejected. The resistance of concrete to chloride ion penetration is represented by the total charge passed, in coulombs, through a water-saturated concrete section during a test period of 6 
$1 \mathrm{~h}$. In this study, the chloride ion penetrability test was carried out on the concrete specimens at the ages of

228 and 180 days, each result was the average of four measurements. Each middle section, which was

3 sourced from a different $100 \varnothing / 200 \mathrm{~mm}$ concrete cylinder, was tested at the same age.

\section{RESULTS AND DISCUSSION}

\subsection{Physical properties}

The results of dry-density, absorption and accessible voids are shown in Table 5. As reported by several authors [39], both the increase in the replacement of coarse recycled aggregates and the poorness of their quality caused the decrease of the dry-density of the RACs and the increase in water absorption. For example, the absorption and void percentages increased by more than $100 \%$ when the total volume of the natural coarse aggregates were replaced by MRA. The higher absorption capacity and the higher volume of voids of MRA affected the final properties of the concretes in which they were used.

However, the concrete made with fine CWA had slightly lower density than that of NAC concrete. The absorption and permeable pore volume of concretes made with CWA were lower than those of NAC. A major quantity of filler particles in fine CWA not only leads to a better filling of pore space than conventional fine aggregate but also an improvement of the durability properties [25]. The water absorbed in fine ceramic aggregates could also produce an internal curing in concretes, improving the cement hydration [40] and consequently lowering the amount of accessible pores. Similarly in concretes made with lightweight aggregates, Cusson and Margeson [41] found that cement hydration was actually enhanced by internal curing which lead to higher C-S-H content.

Pore size distributions of mortar samples taken from concrete specimens were determined for NAC and RAC containing $100 \%$ of RCA100, RCA60 and RCA40 and their results can be observed in Fig. 3. After 1 day of curing (see Fig. 3a), the concrete produced with RCA100 showed significant lower porosity, at any size range, than that of NAC. In NAC, the porosity is higher in the aggregate-paste interface than in the paste itself and the pore size is usually larger [42,43]. Nevertheless, as certain authors have pointed out [2], the ITZ is improved by the use of recycled aggregates, which could explain the reduction of porosity. However, RAC containing lower quality RCA which had higher total water-cement ratios worsened pore size distributions at very early ages. 
1 Fig. 3 b shows the pore size distributions at 28 days of age. While NAC and RAC containing RCA100 and 60 showed similar distributions, RAC-RCA40 had higher capillary pore volumes than NAC. RAC containing RCA100 and 60 could have improved the pore structure by acting as internal curing agents $[31,44]$. Internal curing in HPC leads to lower internal stress and also enhances the cement matrix densification [40]. Furthermore, the pore distribution of RAC-RCA40 could be influenced by the presence of old-mortar attached to the RCA.

\subsection{Mechanical properties}

The compressive strength results for the concrete mixtures are presented in Table 6. RAC mixtures obtained a higher compressive strength than those of NAC after 24 hours, except for RAC containing $100 \%$ of RCA40 or MRA, which obtained similar or $10 \%$ lower results to those of NAC. The remaining absorption capacity of partially saturated recycled aggregates could be responsible for reducing the w/c ratio in the ITZ, thus improving its strength at early hydration [7]. Fig. 4a shows the 28-day, relative compressive strength of all RACs with respect to NAC. The RAC containing coarse RCA sourced from HPC concrete (RCA 100 and 60) or fine CWA achieved higher or similar compressive strength to that of NAC. According to the results obtained from an analysis of the RAC produced with $50 \% 40 \mathrm{MPa}$ recycled aggregates or $20 \%$ MRA aggregate replacement for NA, a lower compressive strength than that of NAC was achieved. As certain authors [6] have pointed out, the quality of the old attached mortar when compared to the new mortar has notable detrimental effects on the mechanical behaviour of the RAC.

The compressive strength test was also carried out on cylindrical specimens at 28 and 180 days (Table 6). The RAC showed a higher compressive strength increase from 28 to 180 days to that of the NAC during the same period of time. Increasing recycled aggregate content produced higher developments of compressive strength. In addition, the concrete produced employing MRA, which was the most porous recycled aggregate type employed, achieved the highest compressive strength increase. The water stored in the recycled aggregates, similarly in behaviour to that of lightweight aggregates, enhanced the cement hydration through internal curing and produced improved mechanical behaviours [16,31].

According to flexural strength results, all the concretes made with the three types of RCA and fine CWA achieved higher or similar strength to that of NAC concrete. The use of MRA on substitution of natural 
coarse aggregates for concrete production had a negative influence on those properties. Only the concrete made with $20 \%$ of MRA obtained similar flexural strength to that of CC.

According to the splitting tensile strength results (see Table 6), all concrete mixtures produced employing RCAs showed an adequate performance, except the concrete mixtures made with $100 \%$ of $40 \mathrm{MPa}$ RCA and MRA. All the other series achieved more than 4.5 MPa of splitting tensile strength, which is the minimum requirement for high performance concrete elements such as railway sleepers [33]. The splitting tensile strength did not appear to be greatly influenced by the RAC replacement level in each recycled aggregate quality used. This fact was probably due to the influence of the ITZ between the cement paste and the coarse aggregate [2]. The concretes made with CWA achieved a similar or higher flexural and splitting strength to those of the NAC.

The modulus of elasticity appeared to be more influenced by recycled aggregates replacement than the other mechanical properties. It is well known that the modulus of elasticity of concrete is influenced by the modulus of elasticity of the coarse aggregate [45] and according to Lydon and Balendran [46], the modulus of elasticity of aggregate is proportional to the square of its density. Despite showing lower elastic modulus values, all the RAC mixtures produced employing RCAs showed high results, the minimum was found to be $37 \mathrm{GPa}$ (RC-100-40). The concretes produced with MRA aggregates also showed high values, the minimum value achieved was $32 \mathrm{GPa}$, corresponding to concrete produced with $100 \%$ replacement aggregates. The concretes produced employing fine CWA achieved nearly $50 \mathrm{GPa}$.

Fig. 4b details a comparative study of the recycled aggregate concretes' modulus of elasticity with respect to that of conventional concrete at 28 days of age. All mixtures showed lower results than the reference NAC, except concrete produced employing 30\% of CWA. The concrete made with $20 \%$ of RCA replacement also showed a reduction close to that of $5 \%$. The use of $100 \%$ of $100 \mathrm{MPa}$ recycled aggregates produced a reduction of modulus of elasticity lower than $10 \%$. Results showed that there was little difference in the modulus of elasticity of the very strong hardened cement paste and that of the aggregate in high performance concrete. However, the difference is much higher in the concretes produced employing RCA with medium strength parent concrete or employing MRA aggregates.

\subsection{Durability properties}


1 The sorptivity values of concretes produced with coarse RCA (RCA100, RCA60 and RCA40) and fine

2 CWA were approximately $0.014 \pm 0.001 \mathrm{~mm} / \mathrm{min}^{1 / 2}$ (see Table 5). When the coarse MRA was employed in 3 concrete production, sorptivity values increased to $0.021-0.036 \mathrm{~mm} / \mathrm{min}^{1 / 2}$. The sorptivity values are significantly lower than those found in other studies for HPC, using slightly higher water-cement ratios [40], which indicates a higher influence of the water-cement ratio, rather than that of the aggregate type used.

7 The results of assessing capillary water absorption during 48 hours of concrete specimens are shown in

8 Fig. 5. Capillary water absorption capacity of the recycled aggregate concretes produced employing

9 coarse RCA or fine CWA were similar or lower to that of the natural aggregate concrete. Concrete made with coarse MRA showed higher capillary absorption capacity than that of NAC. In this study, due to the very low water-cement ratio in the concretes produced, the concretes made employing RCA had increases of the water amount (by weight) in the specimens during the first 30 minutes, which were lower than $0.05 \%$ with respect to the dry weight of the specimens. After 48 hours, the weight in those samples increased approximately by $0.11 \%$ with respect to the initial weight. Consequently, the behaviour of those concretes could be considered as adequate and similar to NAC. The increased water amount (by weight) on the fine CWA concrete specimens was lower than $0.06 \%$ for the reported by other researchers [47-49].

The results of assessing the chloride-ion penetration of the concrete specimens are shown in Fig. 6 (a). In general, the resistance to chloride-ion penetration of concretes produced employing recycled aggregate decreased as the recycled aggregate content increased and as its quality decreased. 
1 The concrete produced employing fine CWA aggregates obtained very good results. Those concretes could be considered as concretes with very low risk to corrosion. The concretes produced employing up to $50 \%$ of three types of RCA, achieved also very low risk status as did the concrete produced with $100 \%$ of the RCA100. In order to obtain very low corrosion risk, $20 \%$ of MRA should be employed for concrete production.

As shown in Fig. 6 (b), the concrete mixtures produced with fine CWA showed the highest resistances to chloride-ion penetration, at the age of 180 days. The reduction of the total charge passed in the NAC concrete from 28 days to 180 days was that of $35 \%$, however the reduction of total charge in concrete RAC-CWA and RAC-MRA was that of 52-70\% and 35-47\%, respectively. In another study [40], as a result of internal curing, similar improvements of chloride-ion penetration resistance were found in concretes produced with low percentages of fine lightweight aggregates in substitution of natural aggregates.

\section{CONCLUSIONS}

The following conclusions can be made based on the results of this study:

- The use of coarse RCA for concrete production reduced and increased concretes' density and absorption capacity, respectively. However, high quality RCA improved the pore structure of the new mortar paste by acting as internal curing agents. Moreover, the employment of fine CWA on substitution for natural aggregates reduced the density as well as the absorption capacity.

- The high performance recycled concrete produced employing up to $100 \%$ of high strength coarse RCA, up to $50 \%$ of medium strength coarse RCA and up to $30 \%$ of fine CWA achieved similar or better compressive, flexural and splitting tensile strengths than the conventional HPC.

- All RAC mixtures showed lower modulus of elasticity results than the reference NAC, except concrete produced employing 30\% of CWA.

- The use of high percentages of MRA for concrete production resulted in lower compressive, flexural and tensile strengths when compared to those of NAC. However, the mentioned MRA concretes achieved the highest compressive strength increase from 28 to 180 days. 
- According to durability, the concrete produced employing 30\% of fine CWA achieved the highest properties. The use of RCA60 and RCA40 were limited to 50\% in order to achieve the properties of conventional high performance concrete. The very high strength recycled aggregate, RCA100, was able to replace the natural aggregates in $100 \%$ in order to achieve the properties of conventional HPC.

According to the results, an emphasis on two aspects could be made; firstly, the concretes produced employing fine ceramic aggregates achieved the highest mechanical and durable properties. Secondly, due to the recycled aggregates' porous structure, which consequently leads to the retention of a certain amount of water, the internal curing caused an improvement in the mechanical and durability properties in high performance recycled aggregate concretes as time went on.

\section{ACKNOWLEDGE}

The authors wish to acknowledge the financial support of The Ministry of Economy and Competitiveness by INNPACT project (IPT-2011-1655-370000) and the support of Vias y Construcciones S.A, and Drace Infraestructuras enterprises.

\section{REFERENCES}

[1] Tu T-Y, Chen Y-Y, Hwang C-L. Properties of HPC with recycled aggregates. Cem Concr Res 2006;36:943-50.

[2] Etxeberria M, Vázquez E, Marí A, Barra M. Influence of amount of recycled coarse aggregates and production process on properties of recycled aggregate concrete. Cem Concr Res 2007;37:735-42.

[3] Tam VWY, Gao XF, Tam CM. Microstructural analysis of recycled aggregate concrete produced from two-stage mixing approach. Cem Concr Res 2005;35:1195-203.

[4] Kikuchi K, Yasunaga A, Ehara K. The total evaluation of recycled aggregate and recycled concrete. 3rd Int. RILEM Syrup. Demolition Reuse Concr. Mason., Odense, Denmark: E \& FN Spon, London; 1993, p. 367-77.

[5] Ravindrajah RS, Loo YH, Tam CT. Strength Evaluation of Recycled Aggregate Concrete by InSitu Tests. Mater Struct 1988;21:289-95.

[6] Tabsh SW, Abdelfatah AS. Influence of recycled concrete aggregates on strength properties of concrete. Constr Build Mater 2009;23:1163-7. 
[7] Poon CS, Shui ZH, Lam L. Effect of microstructure of ITZ on compressive strength of concrete prepared with recycled aggregates. Constr Build Mater 2004;18:461-8.

[8] Etxeberria M, Vázquez E, Marí AR. Microstructure analysis of hardened recycled aggregate concrete. Mag Concr Res 2006;58:683-90.

[9] Limbachiya M, Meddah MS, Ouchagour Y. Use of recycled concrete aggregate in fly-ash concrete. Constr Build Mater 2011;27:439-49.

[10] Poon CS, Kou SC. Properties of steam cured recycled aggregate concrete. In: Limbachiya MC, Roberts J., editors. Constr. Demolition Waste, Proc. Int. Conf. held Univ. Kingst., Kingston upon Thames, London: 2004, p. 1-12.

[11] Xiao J, Li J, Zhang C. Mechanical properties of recycled aggregate concrete under uniaxial loading. Cem Concr Res 2005;35:1187-94.

[12] Topçu İB, Şengel S. Properties of concretes produced with waste concrete aggregate. Cem Concr Res 2004;34:1307-12.

[13] Di Maio AA, Zega CJ, Traversa LP. Estimation of Compressive Strength of Recycled Concrete with the Ultrasonic Method. J ASTM Int 2005;2:1-8.

[14] De Brito J, Pereira AS, Correia JR. Mechanical behaviour of non-structural concrete made with recycled ceramic aggregates. Cem Concr Compos 2005;27:429-33.

[15] Hendricks C. The Building Cycle. Aenas Tech. Pbl. The Nederlans; 2000.

[16] ACI Committee 363. State of the Art Report on High-Strength Concrete. Farmington Hills: 1997.

[17] Poon CS, Chan D. Paving blocks made with recycled concrete aggregate and crushed clay brick. Constr Build Mater 2006;20:569-77.

[18] Binici H. Effect of crushed ceramic and basaltic pumice as fine aggregates on concrete mortars properties. Constr Build Mater 2007;21:1191-7.

[19] Cachim PB. Mechanical properties of brick aggregate concrete. Constr Build Mater 2009;23:1292-7.

[20] Pacheco-Torgal F, Jalali S. Reusing ceramic wastes in concrete. Constr Build Mater 2010;24:832-8.

[21] Senthamarai R, Devadas Manoharan P. Concrete with ceramic waste aggregate. Cem Concr Compos 2005;27:910-3.

[22] Senthamarai R, Manoharan PD, Gobinath D. Concrete made from ceramic industry waste: Durability properties. Constr Build Mater 2011;25:2413-9.

[23] Torkittikul P, Chaipanich A. Utilization of ceramic waste as fine aggregate within Portland cement and fly ash concretes. Cem Concr Compos 2010;32:440-9.

[24] Yang J, Du Q, Bao Y. Concrete with recycled concrete aggregate and crushed clay bricks. Constr Build Mater 2011;25:1935-45.

[25] Heidari A, Tavakoli D. A study of the mechanical properties of ground ceramic powder concrete incorporating nano-SiO 2 particles. Constr Build Mater 2013;38:255-64. 
[26] Khatib JM. Properties of concrete incorporating fine recycled aggregate. Cem Concr Res 2005;35:763-9.

[27] Limbachiya MC, Leelawat T, Dhir RK. Use of recycled concrete aggregate in high-strength concrete. Mater Struct 2000;33:574-80.

[28] Ajdukiewicz A, Kliszczewicz A. Influence of recycled aggregates on mechanical properties of HS/HPC. Cem Concr Compos 2002;24:269-79.

[29] Gonzalez-Corominas A, Etxeberria M. Experimental analysis of properties of high performance recycled aggregate concrete. Constr Build Mater 2014;52:227-35.

[30] Gonzalez-Corominas A, Etxeberria M. Properties of high performance concrete made with recycled fine ceramic and coarse mixed aggregates. Constr Build Mater 2014;68:618-26.

[31] Suzuki M, Seddik Meddah M, Sato R. Use of porous ceramic waste aggregates for internal curing of high-performance concrete. Cem Concr Res 2009;39:373-81.

[32] Vejmelková E, Keppert M, Rovnaníková P, Ondráček M, Keršner Z, Černý R. Properties of high performance concrete containing fine-ground ceramics as supplementary cementitious material. Cem Concr Compos 2012;34:55-61.

[33] ADIF. Spanish Technical Specifications of Prestressed Concrete Monoblock Sleepers (ET 03.360.571.8 ). Madrid: 2009.

[34] Vincke J, Rousseau E. Recycling of Construction and Demolition Waste in Belgium: Actual Situation and Future Evolution. Demolition and Reuse of Concrete and Masonry. In: Lauritzen E., editor. Third Int. RILEM Symp., E\&FN Spon, 2-6 Boundary Row, London SE 1 8HN, First edition; 1994, p. 57-69.

[35] DIN 4226-1:2000: “Concrete Aggregate” 2000.

[36] CPH-Comisión Permanente del Hormigón. Instrucción de Hormigón Estructural. EHE-08 (Spanish Concrete Structural Code) 2009.

[37] Poon CS, Shui ZH, Lam L, Fok H, Kou SC. Influence of moisture states of natural and recycled aggregates on the slump and compressive strength of concrete. Cem Concr Res 2004;34:31-6.

[38] Fuller WB, Thompson SE. The laws of proportioniong concrete. Trans ASCE 1907;59:67-143.

[39] Silva RV, De Brito J, Dhir RK. Properties and composition of recycled aggregates from construction and demolition waste suitable for concrete production. Constr Build Mater 2014;65:201-17.

[40] Zhutovsky S, Kovler K. Effect of internal curing on durability-related properties of high performance concrete. Cem Concr Res 2012;42:20-6.

[41] Cusson D, Margeson J. Development of low-shrinkage high-performance concrete with improved durability. CONSEC'10, Merida, Yucatan, Mexico: n.d., p. 8.

[42] Willis KL, Abell AB, Lange DA. Image-based characterization of cement pore structure using wood's metal intrusion. Cem Concr Res 1998;28:1695-705.

[43] Douglas N. Winslow MDC. Percolation and pore structure in mortars and concrete. Cem Concr Res 1994;24:25-37. 
[44] Corinaldesi V. Mechanical and elastic behaviour of concretes made of recycled-concrete coarse aggregates. Constr Build Mater 2010;24:1616-20.

3 [45] Neville AM. Properties of Concrete. 4th ed. 1995.

[46] Lydon F., Balendran R. Some observations on elastic properties of plain concrete. Cem Concr Res 1986;16:314-24.

[47] Wirquin E, Zaharieva R, Buyle-Bodin F. Use of water absorption by concrete as a criterion of the durability of concrete - application to recycled aggregate concrete. Mater Struct 2000;33:403-8.

[48] Levy SM, Helene P. Durability of recycled aggregates concrete: a safe way to sustainable development. Cem Concr Res 2004;34:1975-80.

[49] Zega CJ, Di Maio AA. Use of recycled fine aggregate in concretes with durable requirements. Waste Manag 2011;31:2336-40. 


\section{LIST OF FIGURES}

Fig. 1. Particle size distribution of coarse aggregate according to ASTM

Fig. 2. Particle size distribution of fine aggregate according to ASTM.

Fig. 3. Pore size cumulative distribution of NAC and RAC containing RCA (100, 60 and 40) at the ages of 1 (a) and 28 days (b).

Fig. 4. Relative compressive strength (a) and Relative elastic modulus (b) of recycled aggregate concretes in comparison with that of natural aggregate concrete at 28 days of age.

Fig 5. Capillary water absorption of concrete mixtures.

Fig. 6. (a) Chloride-ion penetration of all concrete mixtures at 28 days; (b) Chloride-ion penetration evolution over time (28-180 days) of NAC, RAC-CWA and RAC-MRA (Very low and low corrosion risks limits according to ASTM C1202) [30]. 


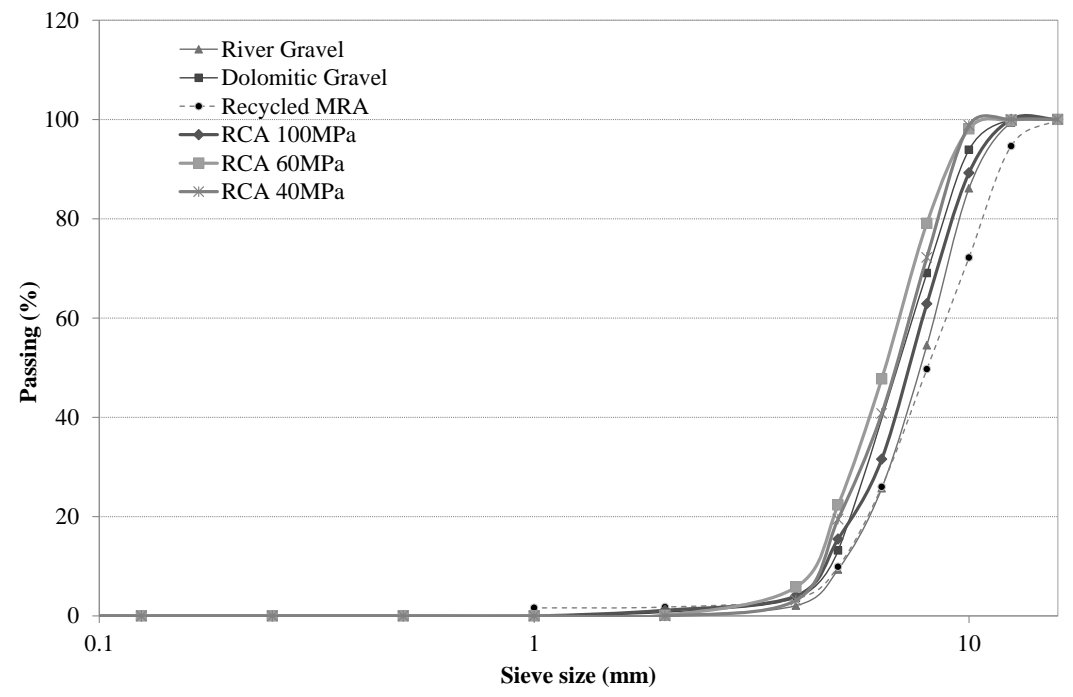

Fig. 1. Particle size distribution of coarse aggregate according to ASTM

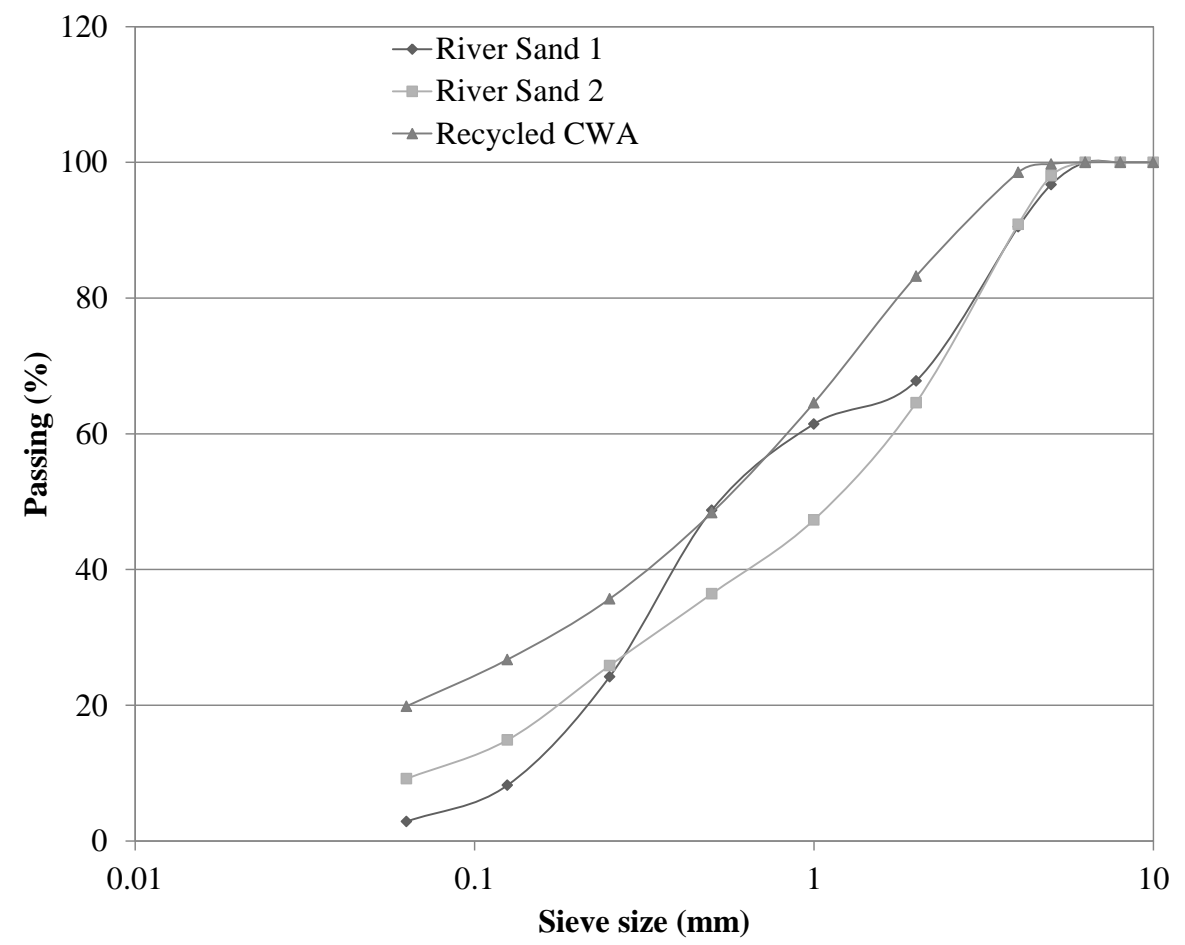

Fig. 2. Particle size distribution of fine aggregate according to ASTM. 


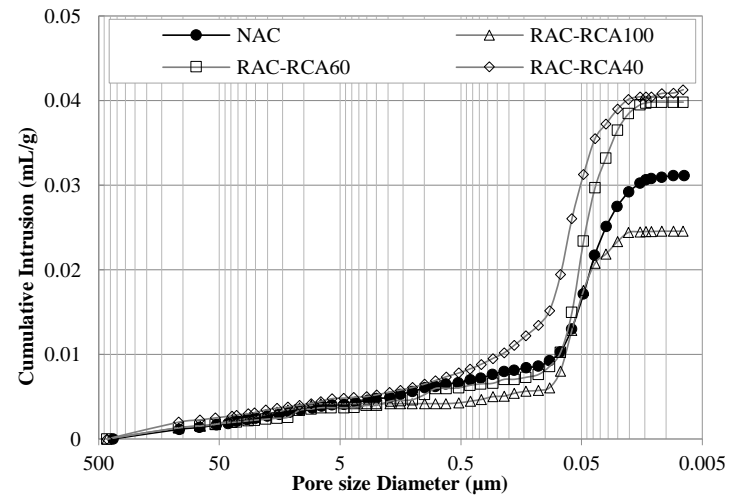

(a)

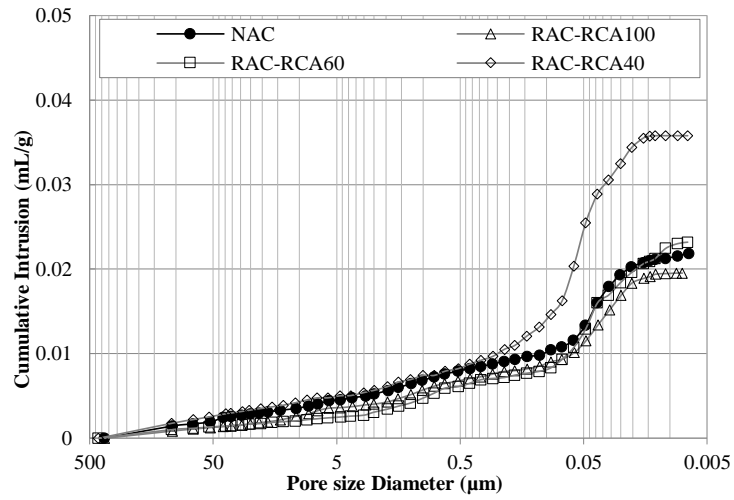

(b)

Fig. 3. Pore size cumulative distribution of NAC and RAC containing RCA (100,60 and 40) at the ages of 1 (a) and 28 days $(b)$.

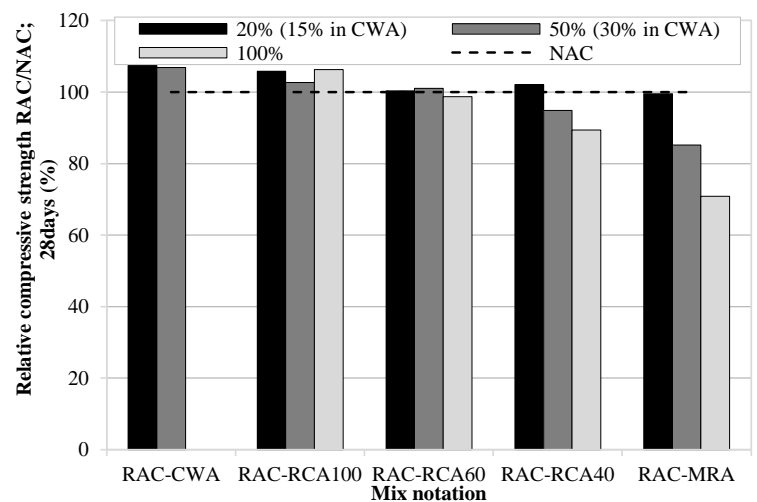

(a)

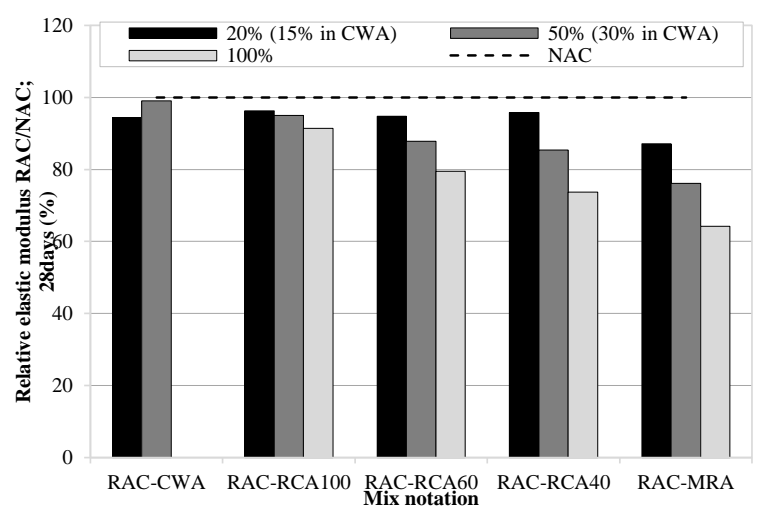

(b)

Fig. 4. Relative compressive strength (a) and Relative elastic modulus (b) of recycled aggregate concretes in comparison with that of natural aggregate concrete at 28 days of age. 


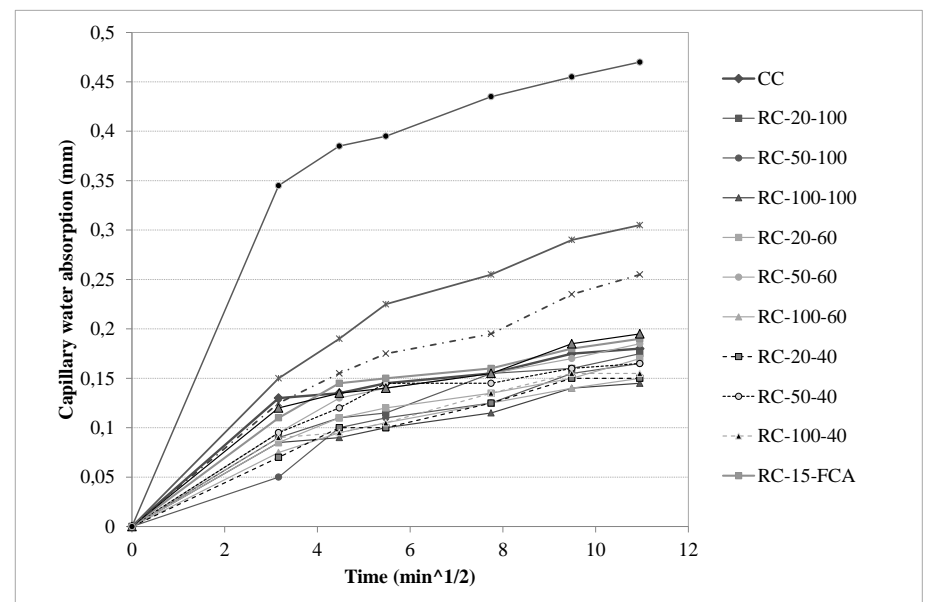

Fig 5. Capillary water absorption of concrete mixtures.
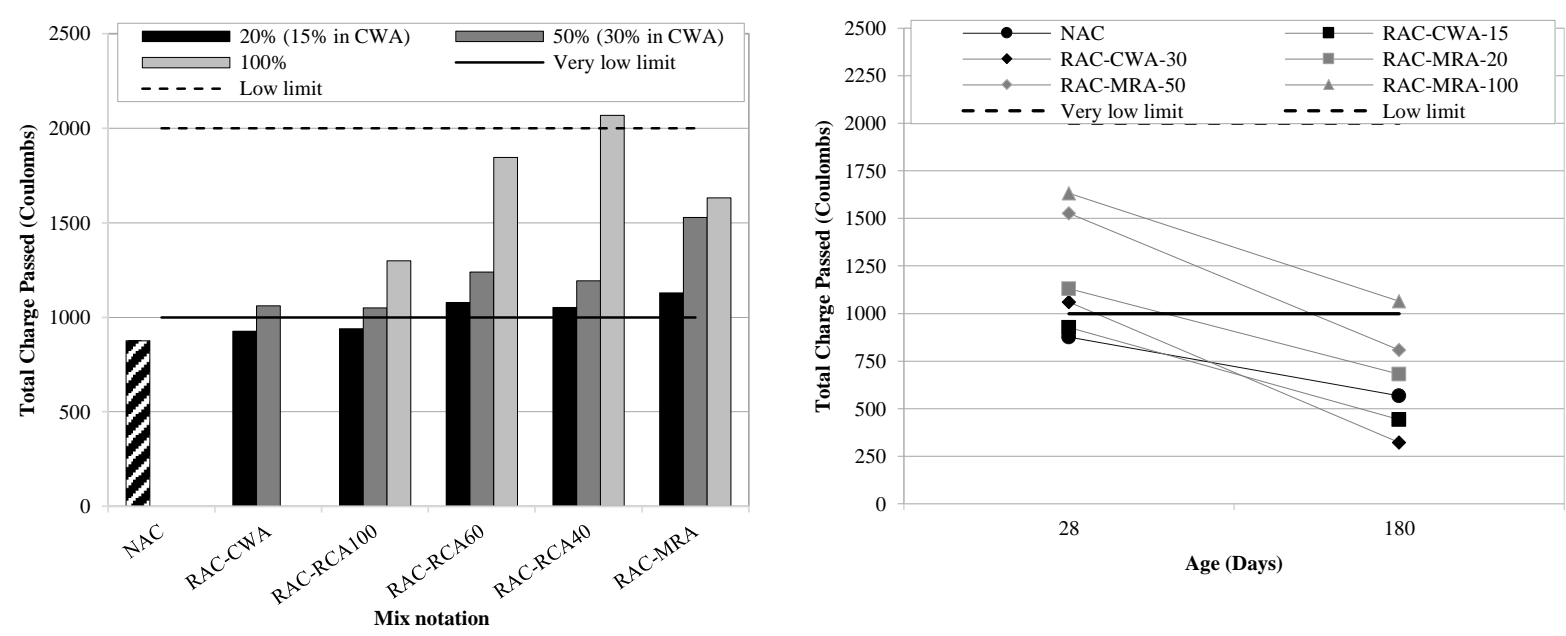

(a)

(b)

Fig. 6. (a) Chloride-ion penetration of all concrete mixtures at 28 days; (b) Chloride-ion penetration evolution over time (28-180 days) of NAC, RAC-CWA and RAC-MRA (Very low and low corrosion risks limits according to ASTM C1202) [30]. 


\section{LIST OF TABLES}

Table 1. Chemical composition of cement

Table 2. Composition of MRA and CWA following UNE-EN 933-11:2009

Table 3. Physical and mechanical properties of natural and recycled aggregates.

Table 4. Proportioning of the concrete mixtures (Coded: Natural Aggregate Concrete, NAC; Recycled concrete mixtures, $\mathrm{RAC}-\mathrm{x}$ ( $\mathrm{x}=$ type of recycled aggregate used).

Table 5. Physical properties and Sorptivity at 28 days (in brackets, standard deviations)

Table 6. Mechanical properties at each corresponding testing age (in brackets, standard deviations) and compressive strength evolution from 28-180 days 
Table 1. Chemical composition of cement

\begin{tabular}{|l|c|c|c|c|c|c|c|c|c|}
\hline Composition & $\mathrm{SiO}_{2}$ & $\mathrm{Al}_{2} \mathrm{O}_{3}$ & $\mathrm{Fe}_{2} \mathrm{O}_{3}$ & $\mathrm{CaO}$ & $\mathrm{MgO}$ & $\mathrm{K}_{2} \mathrm{O}$ & $\mathrm{Cl}^{-}$ & $\mathrm{SO}_{3}$ & LOI \\
\hline$(\%)$ & 21.75 & 3.38 & 4.55 & 64.65 & 1.63 & 0.64 & 0.01 & 2.66 & 0.91 \\
\hline
\end{tabular}

Table 2. Composition of MRA and CWA following UNE-EN 933-11:2009

\begin{tabular}{|l|c|c|c|c|c|c|}
\hline $\begin{array}{l}\text { Composition } \\
(\%)\end{array}$ & $\begin{array}{c}\text { Concrete } \\
\text { products }\end{array}$ & $\begin{array}{c}\text { Unbound } \\
\text { aggregates }\end{array}$ & $\begin{array}{c}\text { Masonry } \\
\text { products }\end{array}$ & $\begin{array}{c}\text { Bituminous } \\
\text { products }\end{array}$ & $\begin{array}{c}\text { Glass } \\
\text { products }\end{array}$ & $\begin{array}{c}\text { Others (Wood, } \\
\text { plastics and } \\
\text { gypsum) }\end{array}$ \\
\hline MRA & 22.2 & 9.8 & 67.3 & 0 & 0.1 & 0.7 \\
\hline CWA & 0 & 0 & 100 & 0 & 0 & 0 \\
\hline
\end{tabular}

Table 3. Physical and mechanical properties of natural and recycled aggregates.

\begin{tabular}{|l|c|c|c|c|c|c|c|c|c|}
\hline & $\begin{array}{c}\text { River } \\
\text { Gravel 4- } \\
12 \mathrm{~mm}\end{array}$ & $\begin{array}{c}\text { Dolomitic } \\
\text { Gravel 4- } \\
10 \mathrm{~mm}\end{array}$ & $\begin{array}{l}\text { River } \\
\text { Sand 1 }\end{array}$ & $\begin{array}{c}\text { River } \\
\text { Sand 2 }\end{array}$ & $\begin{array}{c}\text { RCA100 } \\
4-10 \\
\mathrm{~mm}\end{array}$ & $\begin{array}{c}\text { RCA60 } \\
4-10 \\
\mathrm{~mm}\end{array}$ & $\begin{array}{c}\text { RCA40 } \\
4-10 \\
\mathrm{~mm}\end{array}$ & $\begin{array}{c}\text { MRA } \\
4-10 \\
\mathrm{~mm}\end{array}$ & $\begin{array}{c}\text { Fine } \\
\text { CWA } \\
0-4 \mathrm{~mm}\end{array}$ \\
\hline $\begin{array}{l}\text { Dry particle } \\
\text { density (kg/dm3) }\end{array}$ & 2.61 & 2.68 & 2.50 & 2.57 & 2.47 & 2.39 & 2.30 & 1.80 & 2.00 \\
\hline $\begin{array}{l}\text { Water absorption } \\
(\%)\end{array}$ & 1.29 & 2.13 & 1.02 & 1.93 & 3.74 & 4.90 & 5.91 & 16.45 & 14.37 \\
\hline $\begin{array}{l}\text { Flakiness Index } \\
(\%)\end{array}$ & 17.71 & 7.81 & - & - & 9.59 & 13.57 & 16.53 & 12.00 & - \\
\hline $\begin{array}{l}\text { Abrasion index } \\
(\%)\end{array}$ & 19.61 & 24.77 & - & - & 24.01 & 25.24 & 24.31 & 25.20 & - \\
\hline $\begin{array}{l}\text { Crushing value } \\
(\%)\end{array}$ & 18.93 & 20.15 & - & - & 22.59 & 23.36 & 25.56 & 34.62 & - \\
\hline
\end{tabular}


Table 4. Proportioning of the concrete mixtures (Coded: Natural Aggregate Concrete, NAC; Recycled concrete mixtures, $R A C-x$ ( $x=$ type of recycled aggregate used).

\begin{tabular}{|c|c|c|c|c|c|c|c|c|c|}
\hline Mix notation & $\begin{array}{l}\text { Replaceme } \\
\text { nt ratio }(\%)\end{array}$ & $\begin{array}{c}\text { River } \\
\text { Sand } \\
1\end{array}$ & $\begin{array}{c}\text { River } \\
\text { Sand } \\
2\end{array}$ & $\begin{array}{l}\text { River } \\
\text { Gravel }\end{array}$ & $\begin{array}{c}\text { Dolomit } \\
\text { ic } \\
\text { Gravel }\end{array}$ & RA & $\begin{array}{c}\text { Total } \\
\text { Water } \\
(\mathrm{kg})\end{array}$ & $\begin{array}{l}\text { Cement } \\
(\mathrm{kg})\end{array}$ & $\begin{array}{l}\text { Effective } \\
\text { W/C ratio }\end{array}$ \\
\hline NAC & 0 & 711.8 & 215.2 & 302.1 & 784.5 & - & 135.4 & 380 & 0.285 \\
\hline \multirow{2}{*}{ RAC-CWA } & 15 & 605.0 & 182.9 & 302.0 & 784.5 & 108.6 & 154.1 & 380 & 0.285 \\
\hline & 30 & 498.2 & 150.7 & 302.0 & 784.5 & 217.2 & 166.3 & 380 & 0.285 \\
\hline \multirow{3}{*}{$\begin{array}{l}\text { RAC- } \\
\text { RCA100 }\end{array}$} & 20 & 711.8 & 215.2 & 241.6 & 627.6 & 202.0 & 137.1 & 380 & 0.285 \\
\hline & 50 & 711.8 & 215.2 & 151.0 & 392.2 & 505.1 & 146.5 & 380 & 0.285 \\
\hline & 100 & 711.8 & 215.2 & - & - & $\begin{array}{c}1010 . \\
2\end{array}$ & 162.3 & 380 & 0.285 \\
\hline \multirow{3}{*}{$\begin{array}{l}\text { RAC- } \\
\text { RCA60 }\end{array}$} & 20 & 711.8 & 215.2 & 241.6 & 627.6 & 195.0 & 138.2 & 380 & 0.285 \\
\hline & 50 & 711.8 & 215.2 & 151.0 & 392.2 & 487.5 & 149.8 & 380 & 0.285 \\
\hline & 100 & 711.8 & 215.2 & - & - & 975.1 & 170.4 & 380 & 0.285 \\
\hline \multirow{3}{*}{$\begin{array}{l}\text { RAC- } \\
\text { RCA40 }\end{array}$} & 20 & 711.8 & 215.2 & 241.6 & 627.6 & 187.8 & 139.7 & 380 & 0.285 \\
\hline & 50 & 711.8 & 215.2 & 151.1 & 392.3 & 469.4 & 153.1 & 380 & 0.285 \\
\hline & 100 & 711.8 & 215.2 & - & - & 938.8 & 175.3 & 380 & 0.285 \\
\hline \multirow{3}{*}{ RAC-MRA } & 20 & 711.8 & 215.2 & 241.6 & 627.6 & 147.0 & 160.8 & 380 & 0.285 \\
\hline & 50 & 711.8 & 215.2 & 151.0 & 392.2 & 367.4 & 191.3 & 380 & 0.285 \\
\hline & 100 & 711.8 & 215.2 & - & - & 734.9 & 244.8 & 380 & 0.285 \\
\hline
\end{tabular}


Table 5. Physical properties and Sorptivity at 28 days (in brackets, standard deviations)

\begin{tabular}{|l|l|l|l|l|l|}
\hline \multirow{4}{*}{ Mix notation } & $\begin{array}{l}\text { Replacement } \\
\text { ratio }(\%)\end{array}$ & $\begin{array}{l}\text { Dry-density } \\
\left(\mathrm{Kg} / \mathrm{dm}^{3}\right)\end{array}$ & $\begin{array}{l}\text { Water } \\
\text { Absorption }(\%)\end{array}$ & Voids (\%) & $\begin{array}{l}\text { Sorptivity } \\
\left(\mathrm{mm} / \mathrm{min}^{1 / 2}\right)\end{array}$ \\
\hline NAC & 0 & $2.51(0.01)$ & $1.39(0.04)$ & $3.49(0.09)$ & $0.014(2.6 \mathrm{E}-04)$ \\
\hline \multirow{2}{*}{ RAC-CWA } & 15 & $2.50(0.00)$ & $1.30(0.02)$ & $3.24(0.06)$ & $0.015(9.8 \mathrm{E}-06)$ \\
\cline { 2 - 6 } & 30 & $2.48(0.00)$ & $1.31(0.04)$ & $3.26(0.11)$ & $0.016(1.1 \mathrm{E}-03)$ \\
\hline \multirow{3}{*}{ RAC-RCA100 } & 20 & $2.50(0.00)$ & $1.24(0.01)$ & $3.10(0.02)$ & $0.015(7.2 \mathrm{E}-04)$ \\
\cline { 2 - 6 } & 50 & $2.48(0.01)$ & $1.51(0.07)$ & $3.72(0.16)$ & $0.015(6.3 \mathrm{E}-04)$ \\
\cline { 2 - 6 } & 100 & $2.43(0.01)$ & $1.51(0.05)$ & $3.67(0.12)$ & $0.013(5.6 \mathrm{E}-04)$ \\
\cline { 2 - 6 } & 20 & $2.44(0.08)$ & $1.76(0.06)$ & $4.44(0.01)$ & $0.014(6.7 \mathrm{E}-04)$ \\
\cline { 2 - 6 } & 100 & $2.40(0.05)$ & $1.93(0.08)$ & $4.64(0.29)$ & $0.014(4.2 \mathrm{E}-04)$ \\
\hline \multirow{3}{*}{ RAC-RCA40 } & 20 & $2.34(0.01)$ & $2.43(0.04)$ & $5.69(0.13)$ & $0.013(4.3 \mathrm{E}-04)$ \\
\cline { 2 - 6 } & 50 & $2.47(0.00)$ & $2.08(0.04)$ & $5.14(0.10)$ & $0.013(1.1 \mathrm{E}-03)$ \\
\cline { 2 - 6 } & 100 & $2.43(0.01)$ & $2.12(0.08)$ & $5.16(0.19)$ & $0.014(4.8 \mathrm{E}-04)$ \\
\hline \multirow{3}{*}{ RAC-MRA } & 20 & $2.39(0.00)$ & $2.17(0.08)$ & $5.20(0.18)$ & $0.014(1.5 \mathrm{E}-04)$ \\
\cline { 2 - 6 } & 50 & $2.43(0.01)$ & $1.88(0.04)$ & $4.55(0.10)$ & $0.021(1.3 \mathrm{E}-03)$ \\
\cline { 2 - 6 } & 100 & $2.35(0.01)$ & $2.48(0.07)$ & $5.83(0.43)$ & $0.026(2.9 \mathrm{E}-04)$ \\
\hline
\end{tabular}


Table 6. Mechanical properties at each corresponding testing age (in brackets, standard deviations) and compressive strength evolution from 28-180 days

\begin{tabular}{|c|c|c|c|c|c|c|c|c|c|c|}
\hline \multirow{3}{*}{$\begin{array}{l}\text { Mix } \\
\text { notation }\end{array}$} & \multirow{3}{*}{$\begin{array}{l}\text { Replaceme } \\
\text { nt ratio }(\%)\end{array}$} & \multicolumn{6}{|c|}{ Compressive strength (MPa) } & \multirow{3}{*}{\begin{tabular}{|l|} 
Flexura \\
$1(\mathrm{MPa})$ \\
7 days \\
\end{tabular}} & \multirow{3}{*}{$\begin{array}{l}\text { Splitting } \\
\text { tensile } \\
\text { strength } \\
\text { (MPa) } \\
28 \text { days }\end{array}$} & \multirow{3}{*}{$\begin{array}{l}\begin{array}{l}\text { Elastic } \\
\text { modulus } \\
(\mathrm{GPa})\end{array} \\
28 \text { day }\end{array}$} \\
\hline & & \multicolumn{3}{|c|}{ Cubic specimens } & \multicolumn{3}{|c|}{ Cylindrical specimens } & & & \\
\hline & & 1 day & $\begin{array}{l}7 \\
\text { days }\end{array}$ & $\begin{array}{l}28 \\
\text { days }\end{array}$ & $\begin{array}{l}28 \\
\text { days }\end{array}$ & $\begin{array}{l}180 \\
\text { days }\end{array}$ & $\begin{array}{l}\text { gain } \\
28-180 \\
\text { days }(\%)\end{array}$ & & & \\
\hline NAC & 0 & $\begin{array}{l}57.4 \\
(2.5) \\
\end{array}$ & \begin{tabular}{|l|}
91.2 \\
$(5.7)$ \\
\end{tabular} & $\begin{array}{l}102.1 \\
(6.6) \\
\end{array}$ & $\begin{array}{l}90.7 \\
(4.8) \\
\end{array}$ & \begin{tabular}{|l|}
100.1 \\
$(0.3)$ \\
\end{tabular} & 10 & $\begin{array}{c}6.5 \\
(0.2) \\
\end{array}$ & $\begin{array}{c}5.1 \\
(0.4) \\
\end{array}$ & $\begin{array}{l}50.4 \\
(1.2) \\
\end{array}$ \\
\hline \multirow{2}{*}{ RAC-CWA } & 15 & $\begin{array}{l}72.1 \\
(0.4) \\
\end{array}$ & \begin{tabular}{|l|}
90.0 \\
$(4.0)$ \\
\end{tabular} & \begin{tabular}{|c|}
109.7 \\
$(3.1)$ \\
\end{tabular} & $\begin{array}{l}97.0 \\
(3.1) \\
\end{array}$ & \begin{tabular}{|c|}
108.8 \\
$(3.8)$ \\
\end{tabular} & 12 & $\begin{array}{c}8.3 \\
(0.2) \\
\end{array}$ & $\begin{array}{c}5.1 \\
(0.2) \\
\end{array}$ & $\begin{array}{l}47.6 \\
(1.2) \\
\end{array}$ \\
\hline & 30 & $\begin{array}{l}67.6 \\
(1.6) \\
\end{array}$ & \begin{tabular}{|l|}
93.4 \\
$(0.6)$ \\
\end{tabular} & $\begin{array}{c}109.1 \\
(2.1) \\
\end{array}$ & $\begin{array}{l}97.4 \\
(0.9) \\
\end{array}$ & \begin{tabular}{|c|}
118.6 \\
$(1.1)$ \\
\end{tabular} & 22 & $\begin{array}{c}6.6 \\
(0.2) \\
\end{array}$ & $\begin{array}{c}5.2 \\
(0.1) \\
\end{array}$ & $\begin{array}{l}50.0 \\
(1.3) \\
\end{array}$ \\
\hline \multirow{3}{*}{$\begin{array}{l}\text { RAC- } \\
\text { RCA100 }\end{array}$} & 20 & $\begin{array}{l}73.8 \\
(0.6) \\
\end{array}$ & \begin{tabular}{|l|}
88.5 \\
$(3.8)$ \\
\end{tabular} & $\begin{array}{l}108.0 \\
(4.9) \\
\end{array}$ & $\begin{array}{l}92.3 \\
(5.2) \\
\end{array}$ & \begin{tabular}{|l}
101.5 \\
$(3.2)$ \\
\end{tabular} & 10 & $\begin{array}{c}7.4 \\
(0.3) \\
\end{array}$ & $\begin{array}{c}5.7 \\
(0.4) \\
\end{array}$ & $\begin{array}{l}48.5 \\
(1.0) \\
\end{array}$ \\
\hline & 50 & $\begin{array}{l}79.2 \\
(2.9) \\
\end{array}$ & \begin{tabular}{|l|}
94.8 \\
$(1.5)$ \\
\end{tabular} & $\begin{array}{c}104.8 \\
(6.3) \\
\end{array}$ & $\begin{array}{l}95.8 \\
(6.3)\end{array}$ & \begin{tabular}{|l|}
106.9 \\
$(4.2)$ \\
\end{tabular} & 12 & $\begin{array}{c}7.7 \\
(0.8) \\
\end{array}$ & $\begin{array}{c}5.6 \\
(0.3) \\
\end{array}$ & $\begin{array}{l}47.9 \\
(2.0) \\
\end{array}$ \\
\hline & 100 & $\begin{array}{l}78.7 \\
(3.3) \\
\end{array}$ & \begin{tabular}{|l|}
93.4 \\
$(3.7)$ \\
\end{tabular} & $\begin{array}{c}108.5 \\
(4.5) \\
\end{array}$ & $\begin{array}{l}89.5 \\
(3.6) \\
\end{array}$ & \begin{tabular}{|l|}
107.6 \\
$(5.3)$ \\
\end{tabular} & 20 & $\begin{array}{c}6.8 \\
(0.3) \\
\end{array}$ & $\begin{array}{c}5.1 \\
(0.3) \\
\end{array}$ & $\begin{array}{l}46.1 \\
(0.5) \\
\end{array}$ \\
\hline \multirow{3}{*}{$\begin{array}{l}\text { RAC- } \\
\text { RCA60 }\end{array}$} & 20 & $\begin{array}{l}73.6 \\
(1.8) \\
\end{array}$ & \begin{tabular}{|c|}
102.1 \\
$(0.5)$ \\
\end{tabular} & $\begin{array}{c}102.5 \\
(1.6) \\
\end{array}$ & $\begin{array}{l}87.9 \\
(4.6) \\
\end{array}$ & \begin{tabular}{|l|}
95.1 \\
$(2.5)$ \\
\end{tabular} & 8 & $\begin{array}{c}8.0 \\
(0.4) \\
\end{array}$ & $\begin{array}{c}6.3 \\
(0.4) \\
\end{array}$ & $\begin{array}{l}47.8 \\
(1.2) \\
\end{array}$ \\
\hline & 50 & $\begin{array}{l}72.4 \\
(0.1) \\
\end{array}$ & \begin{tabular}{|l|}
98.8 \\
$(5.0)$ \\
\end{tabular} & $\begin{array}{l}103.1 \\
(2.8) \\
\end{array}$ & $\begin{array}{l}83.1 \\
(4.0) \\
\end{array}$ & \begin{tabular}{|l|}
97.2 \\
$(1.7)$ \\
\end{tabular} & 17 & $\begin{array}{c}6.8 \\
(0.2) \\
\end{array}$ & $\begin{array}{c}5.1 \\
(0.3) \\
\end{array}$ & $\begin{array}{l}44.3 \\
(0.3) \\
\end{array}$ \\
\hline & 100 & $\begin{array}{l}79.4 \\
(1.0) \\
\end{array}$ & \begin{tabular}{|c|}
100.1 \\
$(3.4)$ \\
\end{tabular} & \begin{tabular}{|c|}
100.8 \\
$(4.9)$ \\
\end{tabular} & $\begin{array}{l}80.8 \\
(5.8) \\
\end{array}$ & \begin{tabular}{|l|}
92.8 \\
$(4.9)$ \\
\end{tabular} & 15 & $\begin{array}{c}6.3 \\
(0.5) \\
\end{array}$ & $\begin{array}{c}5.9 \\
(0.2) \\
\end{array}$ & $\begin{array}{l}40.1 \\
(0.3) \\
\end{array}$ \\
\hline \multirow{3}{*}{$\begin{array}{l}\text { RAC- } \\
\text { RCA40 }\end{array}$} & 20 & $\begin{array}{l}67.1 \\
(1.4) \\
\end{array}$ & \begin{tabular}{|l|}
91.7 \\
$(0.2)$ \\
\end{tabular} & \begin{tabular}{|l|}
104.3 \\
$(4.8)$ \\
\end{tabular} & $\begin{array}{l}83.8 \\
(3.2) \\
\end{array}$ & \begin{tabular}{|l|}
94.2 \\
$(5.3)$ \\
\end{tabular} & 12 & $\begin{array}{c}6.7 \\
(0.4) \\
\end{array}$ & $\begin{array}{c}5.3 \\
(0.3) \\
\end{array}$ & $\begin{array}{l}48.3 \\
(1.9) \\
\end{array}$ \\
\hline & 50 & $\begin{array}{l}60.7 \\
(2.6) \\
\end{array}$ & \begin{tabular}{|l|}
84.4 \\
$(0.9)$ \\
\end{tabular} & \begin{tabular}{|l|}
96.8 \\
$(1.8)$ \\
\end{tabular} & $\begin{array}{l}81.2 \\
(1.7) \\
\end{array}$ & \begin{tabular}{|l|}
95.6 \\
$(0.8)$ \\
\end{tabular} & 18 & $\begin{array}{c}6.8 \\
(0.4) \\
\end{array}$ & $\begin{array}{c}6.2 \\
(0.5) \\
\end{array}$ & $\begin{array}{l}43.0 \\
(0.4) \\
\end{array}$ \\
\hline & 100 & $\begin{array}{l}56.6 \\
(1.1) \\
\end{array}$ & \begin{tabular}{|l|}
79.9 \\
$(3.5)$ \\
\end{tabular} & $\begin{array}{l}91.2 \\
(5.6) \\
\end{array}$ & $\begin{array}{l}72.2 \\
(4.6) \\
\end{array}$ & \begin{tabular}{|l|}
86.6 \\
$(2.1)$ \\
\end{tabular} & 20 & $\begin{array}{c}6.5 \\
(0.1) \\
\end{array}$ & $\begin{array}{c}4.2 \\
(0.0) \\
\end{array}$ & $\begin{array}{l}37.2 \\
(0.5) \\
\end{array}$ \\
\hline \multirow{3}{*}{ RAC-MRA } & 20 & $\begin{array}{l}73.9 \\
(3.3) \\
\end{array}$ & \begin{tabular}{|l|}
97.4 \\
$(0.7)$ \\
\end{tabular} & \begin{tabular}{|c|}
101.6 \\
$(5.5)$ \\
\end{tabular} & $\begin{array}{l}79.6 \\
(2.2) \\
\end{array}$ & \begin{tabular}{|c|}
95.6 \\
$(3.8)$ \\
\end{tabular} & 20 & $\begin{array}{c}6.9 \\
(0.0) \\
\end{array}$ & $\begin{array}{c}4.6 \\
(0.3) \\
\end{array}$ & $\begin{array}{l}43.9 \\
(0.9) \\
\end{array}$ \\
\hline & 50 & $\begin{array}{l}64.0 \\
(1.1) \\
\end{array}$ & \begin{tabular}{|l|}
84.2 \\
$(4.4)$ \\
\end{tabular} & \begin{tabular}{|l|}
87.0 \\
$(2.1)$ \\
\end{tabular} & $\begin{array}{l}66.4 \\
(4.5) \\
\end{array}$ & \begin{tabular}{|l|}
79.7 \\
$(3.3)$ \\
\end{tabular} & 20 & $\begin{array}{c}5.5 \\
(0.0) \\
\end{array}$ & $\begin{array}{c}4.5 \\
(0.3) \\
\end{array}$ & $\begin{array}{l}38.4 \\
(0.3) \\
\end{array}$ \\
\hline & 100 & $\begin{array}{l}52.1 \\
(2.5) \\
\end{array}$ & $\begin{array}{l}66.9 \\
(1.0) \\
\end{array}$ & $\begin{array}{l}72.3 \\
(2.1) \\
\end{array}$ & $\begin{array}{l}53.0 \\
(0.9) \\
\end{array}$ & $\begin{array}{l}69.2 \\
(1.1) \\
\end{array}$ & 31 & $\begin{array}{c}5.3 \\
(0.1) \\
\end{array}$ & $\begin{array}{c}4.2 \\
(0.2) \\
\end{array}$ & $\begin{array}{l}32.4 \\
(0.8) \\
\end{array}$ \\
\hline
\end{tabular}

